Sebastian Kubala

Cracow University of Economics, Poland

ChrYstian FiRLEJ

University of Agriculture in Krakow, Poland

\title{
Self-sufficiency in cereal and potato production in Central and Eastern Europe: 2005-2019
}

\begin{abstract}
The article's main objective is to discuss changes in self-sufficiency levels in cereal and potato production in eleven selected Central and Eastern European (CEE) countries belonging to the EU, defined as the ratio of domestic consumption of certain agricultural products to domestic production. The research period covered the years 2005 to 2019. The article focuses on the technical and economic self-sufficiency of the countries analysed. It was found that CEE countries show a significant degree of diversity in terms of self-sufficiency of cereal and potato production. The most successful in these terms were Lithuania and Poland while the least - Slovenia.
\end{abstract}

Keywords: agricultural development; food security; food self-sufficiency; plant production

Received: 21 October 2020

Accepted: 12 February 2021

\section{Suggested citation:}

Kubala, S., Firlej, Ch. (2021). Self-sufficiency in cereal and potato production in Central and Eastern Europe: 2005-2019. Przedsiębiorczość - Edukacja [Entrepreneurship - Education], 17(1), 177-188. https://doi.org/ 10.24917/20833296.171.14

\section{Introduction}

The traditional food security concept is to achieve the greatest possible self-sufficiency in food production in a given country. However, in conditions of progressive globalisation, this has been replaced by a strategy based on economic security. This situation applies in particular to highly developed countries whose share in the global market is significant. Therefore, the current globalisation processes may lead countries to abandon their production favouring external supply (Kowalczyk, Sobiecki, 2011). However, some countries, especially underdeveloped ones, emphasise the food supply's internal sources that require maintaining agricultural production at a sufficiently high level (Borch, Kjaernes, 2016; Wilkin, 2001). 
The financial and economic crisis of 2006-2009, which triggered a significant increase in food prices, was of great significance for the deepening of hunger in the world. This made food security a key challenge for agriculture in the EU since, according to the estimates of the UN Food and Agriculture Organization, demand for food is going to double by 2050 (Lyon, 2010).

The present-day development of the global economy and that of the EU places great emphasis on maintaining food security. In the EU, food security policy covers a whole chain of actions, which include animal breeding, promoting food hygiene, disseminating food information, preventing food contamination, taking care of plant health and animal welfare, and producing food for consumption.

In Poland, one of the main objectives of the Strategy for Sustainable Development of Rural Agriculture and Fisheries 2030 is also to ensure food security and is related to enabling farms to be capable of restoring production potential and maintaining non-productive functions (Strategia zrównoważonego rozwoju wsi..., 2030).

The primary measure related to food security is food self-sufficiency which has been dealt with by many researchers, among others: F. Kapusta (2011), A. Baer-Nawrocka (2014), J.C. Bureau and J. Swinnen (2018), and S. Kubala (2018). Studying the level of self-sufficiency is extremely important for several reasons. C. Servolin (2005) indicated that sufficient food is the most basic need in all national economies and indicates the degree of agricultural development. This, in turn, implies the need for enterprising management of farms that will be able to restore production potential and maintain essential non-production functions. At the same time, a significant event in the EU's history was the enlargement of its structure to include countries located in the central-eastern part of Europe. This made it possible to open new markets for producers while at the same time increasing the level of competition between individual markets. Therefore, this article's main objective is to examine self-sufficiency levels in cereal and potato production in selected CEE EU countries.

\section{Food security in a theoretical perspective}

The concept of food security appeared in the early 1970s in texts on food policy (FAO, 2003). Food security includes food self-sufficiency and its physical and economic availability (Grębowiec, 2012). The changing approach to defining this concept has arisen, among other things, from the variability of food policy at both national and international levels (Mikuła, 2012).

The official definition of 'food security' was first proposed at the 1974 World Food Conference in Rome. According to it, food security is the "availability at all times of adequate, nourishing, diverse, balanced and moderate world food supplies of basic foodstuffs to sustain a steady expansion of food consumption and to offset fluctuations in production and prices" (FAO, 2003). In 1996, at the World Food Summit held in Rome, it was agreed that "food security, at the individual, household, national, regional and global levels [...] exists when all people, at all times, have physical and economic access to sufficient, safe and nutritious food to meet their dietary needs and food preferences for an active and healthy life" (Rome Declaration..., 1996).

In Poland, food security issues have been included in the national security strategy which defines them as "a situation in which all households have real access to the food 
needed by all people and are not at risk of losing this access" (Sektorowa strategia bezpieczeństwa..., 2008). In 2019 Poland was ranked $24^{\text {th }}$ on the Global Food Security Index with 75.6 points, which is an advance from $26^{\text {th }}$ position in 2018 (75.4 points) (Global Food Security Index, 2020).

Every society should strive for food security in three dimensions: international, state and household (Johnson, 2002; Kapusta, 2012). Considerations here concern the dimension of state food security. According to Kapusta, for state food security to be guaranteed, four conditions must be simultaneously met (Kapusta, 2012):

1. physical availability of food - the national food economy ensures that the minimum physiological demand is covered; the task of imports is to provide food beyond the minimum demand,

2. durability and reliability of food supply,

3. economic availability of food - that the economically weakest households and their members have access to necessary food (thanks to various forms of food aid),

4. health suitability of each food type and the quantity consumed (necessary energy level, proportions of nutrients, no unacceptable impurities).

One of the most critical aspects of food security is the physical availability of food. This comes down mainly to ensuring an adequate supply of this strategic commodity. Hence, it is a series of products necessary to meet a state's inhabitants' minimum physiological needs. Food self-sufficiency in this context is understood as balancing trade in foreign agricultural and food products while covering the demand for basic products on its own (Carletto, Zezza, Banerjee, 2013; Nietupski, Szybiga, 2002).

Food security is dependent on many factors, all of which influence its level. The most frequently mentioned include the level of agricultural development, nature of demographic processes, fluctuations in food and energy markets, technical progress, labour productivity in agriculture, rapid development of biofuels, infrastructure, natural and climatic conditions and occurrences of natural disasters, limited land availability, loss of biodiversity, food waste, changes in consumption patterns, increased global demand for food, political instability, inequality before the law and corruption (Kraciuk, 2013; Kwasek, Obiedzińska, 2013). F. Burchi, J. Fanzo and E. Frison point to three main determinants for food security and food safety, presented in Table 1.

Table 1. Food security and food safety determinants

\begin{tabular}{|l|l|l|}
\hline \multicolumn{1}{|c|}{ Food and nutrition security } \\
\hline \multicolumn{1}{|c|}{ food availability } & \multicolumn{1}{c|}{ food access } & \multicolumn{1}{c|}{ food utility } \\
- food production & - household incomes & - quality of nutrition \\
(knowledge, tradition) & - housing and sanitary \\
- food imports & - food prices & conditions \\
- food aid & - social transfers and loans & quality of healthcare \\
- storage and processing & - functioning of markets & quality of childcare \\
& - transport/distribution & \\
\hline
\end{tabular}

Source: Burchi, Fanzo, Frison (2011: 358-373) 
Food self-sufficiency as a measure of food security

Food self-sufficiency has long been synonymous with food security and used as one of its measures, but its importance in ensuring food security has changed over the years due to changes in individual countries' economic life (Anderson, Strut, 2012; Baer, 2002). The EU's Common Agricultural Policy (CAP) was an EU programme that from the very beginning had social objectives and focused on helping agricultural producers (Tomczak, 2009), and was initially related to ensuring food self-sufficiency for the societies of European countries (Poczta, 2011). Intensification of agricultural production in the EU contributed to achieving this goal (Sadowski, Girzycka, 2012).

In the literature, food self-sufficiency can be understood as:

1. the possibility of covering food needs from national resources alone, with a total elimination of imports,

2. satisfying the food needs of the population from domestic production even with large-scale imports, which should be compensated for by appropriate exports. (The population should be guaranteed basic food products from domestic production, and the missing food and agricultural raw materials should be purchased abroad balancing imports with exports) (Gulbicka, Kwasek, Obiedzińska, 2015)

Food self-sufficiency can also be considered on a global scale. It depends not only on agricultural production and freedom of trade but also on processing and distribution developments. Today, food production in the world is sufficient to feed its population (Bne Saad, 2013). In some regions, however malnutrition is caused by imperfect food distribution and unfavourable political and institutional conditions (Skrzypczyńska, 2011).

Food self-sufficiency can be understood differently in the context of an open or a closed economy. In a 'closed' economy, it is defined as an economy's ability to produce all or most of the food required. It is measured by the relation between the national production of agri-food products and its domestic consumption (Hałasiewicz, 2011). In countries with an 'open' economy, food self-sufficiency can mean the economic and physical availability of food on the internal market, regardless of whether it comes from domestic production or imports. It is most often measured by the balance of trade in agrifood products (Szczepaniak, 2012).

The importance of food self-sufficiency was recognised during the economic crisis in 2006-2007. As a result, a return to a high self-sufficiency policy is to be achieved by equating food consumption with domestic production. Particular attention was paid to the adverse effects of the dependence of a national population's nutrition on importing basic food products, contributing to a reduction in the degree of national food security (Gulbicka, 2009).

\section{Sources and research methodology}

Eleven countries from the CEE region were used as a research area: Bulgaria (BG), Croatia (HR), Czechia (CZ), Estonia (EE), Lithuania (LT), Latvia (LV), Poland (PL), Romania (RO), Slovakia (SK), Slovenia (SI) and Hungary (HU). The article considers two agricultural markets, cereal and potato, which are two of the largest production areas of agricultural raw materials of plant origin in the CEE region. 
The research used simplified self-sufficiency indicators based on the measures proposed by K. Szybiga (2013) and F. Kapusta (2011) with a focus on technical and economic self-sufficiency. The first one was based on research into the foreign trade balance in terms of volume, calculation of indicators representing the volume of production in terms of the number of inhabitants, and the volume of consumption relative to production volume. Economic self-sufficiency was based on research into the foreign trade balance in terms of value.

The research was conducted in the CEE countries concerned for 2005-2019. Concerning indicators relating to the volume of consumption, it was limited to 2005-2017, due to the lack of statistical material. The statistical sources used come from Eurostat and World International Trade databases.

\section{Results of the research}

In the first stage of the research, an evaluation was made of the two agricultural raw materials' production volume as a per capita indicator in the selected CEE countries. The calculated values indicate significant disproportions (Table 2).

The cereal market has a relatively high production per capita volume, with average values for 2005-2019 ranging from $620 \mathrm{~kg} /$ person to $1170 \mathrm{~kg} /$ person. Smaller volumes are found on the potato market, where the average ranges from $75 \mathrm{~kg} /$ person to $138 \mathrm{~kg} /$ person.

While making a detailed analysis, it can be noticed that in the case of cereals, the index values are above the average in Hungary, Lithuania (except 2006), Bulgaria (except 2005 and 2007), Latvia (except 2005-2006 and 2008-2011), and Romania (except 2007-2009, 2012 and 2015). In other countries, these values were either higher than the average in individual years only (Croatia, Czechia, Estonia, Poland) or such cases were not recorded at all (Slovakia, Slovenia). There is much greater homogeneity in the potato market. Values higher than the average are reached by four countries every year: Lithuania, Latvia, Poland and Romania (of which since 2009 the highest level has been in Poland). On the other hand, the lowest values can be found in most of the research period in Bulgaria and Slovakia.

By studying changes between 2005 and 2019, various trends can be seen depending on the agricultural market in question. In practically all countries on the cereal market, there is an increase in production volume per capita with the highest values in Latvia, Lithuania and Estonia (increasing by $182.01 \%, 122.46 \%$ and $119.33 \%$ respectively). Romania is also characterised by a relatively high growth (increase in the index value by $70.96 \%$ ). In Czechia and Hungary, however, there are downward trends. There is a fall in production per capita on the potato market in all countries between 2005 and 2019. The most significant decrease is recorded in Latvia and Slovenia (by $60.18 \%$ and $56.22 \%$ respectively), while the lowest in Romania and Croatia (by $19.97 \%$ and $32.97 \%$ respectively). The main reason for this was the increasing competitive pressure on countries exporting potatoes from Western Europe and limiting the fodder use of potatoes (Firlej, Kubala, 2018).

Other indicators showing the level of self-sufficiency are those relating to the foreign trade balance. On the cereal market (Table 3), most CEE countries export cereals rather than import, and this is how cereal harvest surpluses are used in the EU. The only 
exception is Slovenia which in all the years analysed had a negative trade balance in terms of value and by unit. In Poland, imports exceeded exports in 2006-2008 and 2011. Comparing 2005 and 2019 in terms of value, all the countries improved trade balance, with Estonia and Romania to the greatest extent. In quantitative terms, a deterioration of the foreign trade balance was recorded only in Czechia.

Table 2. Production volume index per capita in individual CEE countries: 2005-2019 (kg/person)

\begin{tabular}{|c|c|c|c|c|c|c|c|c|c|c|c|}
\hline \multicolumn{12}{|c|}{ Cereal market } \\
\hline & BG & HR & $\mathrm{CZ}$ & $\mathrm{EE}$ & $\mathrm{HU}$ & LV & LT & PL & RO & SK & SI \\
\hline 2005 & 760 & 713 & 751 & 559 & 1606 & 584 & 838 & 705 & 905 & 667 & 289 \\
\hline 2006 & 725 & 710 & 625 & 458 & 1436 & 520 & 565 & 571 & 741 & 545 & 246 \\
\hline 2007 & 433 & 592 & 698 & 655 & 959 & 695 & 928 & 712 & 370 & 520 & 265 \\
\hline 2008 & 959 & 871 & 809 & 645 & 1676 & 771 & 1065 & 726 & 815 & 770 & 288 \\
\hline 2009 & 885 & 805 & 751 & 654 & 1355 & 769 & 1196 & 782 & 728 & 619 & 262 \\
\hline 2010 & 981 & 699 & 657 & 509 & 1224 & 677 & 890 & 704 & 824 & 477 & 278 \\
\hline 2011 & 1045 & 659 & 790 & 580 & 1370 & 681 & 1057 & 691 & 1032 & 689 & 297 \\
\hline 2012 & 981 & 623 & 628 & 748 & 1044 & 1039 & 1550 & 737 & 638 & 562 & 280 \\
\hline 2013 & 1286 & 745 & 714 & 739 & 1374 & 963 & 1506 & 735 & 1044 & 631 & 222 \\
\hline 2014 & 1335 & 699 & 835 & 928 & 1677 & 1113 & 1741 & 825 & 1107 & 869 & 315 \\
\hline 2015 & 1212 & 657 & 777 & 1168 & 1431 & 1521 & 2083 & 723 & 973 & 702 & 303 \\
\hline 2016 & 1250 & 829 & 815 & 710 & 1688 & 1373 & 1773 & 772 & 1101 & 893 & 309 \\
\hline 2017 & 1371 & 645 & 705 & 997 & 1427 & 1381 & 1782 & 825 & 1382 & 641 & 265 \\
\hline 2018 & 1434 & 796 & 657 & 697 & 1523 & 1064 & 1424 & 692 & 1616 & 742 & 289 \\
\hline 2019 & 1590 & 864 & 718 & 1226 & 1595 & 1648 & 1864 & 749 & 1547 & 761 & 309 \\
\hline \multicolumn{12}{|c|}{ Potato market } \\
\hline & BG & HR & $\mathrm{CZ}$ & EE & $\mathrm{HU}$ & LV & LT & PL & RO & SK & SI \\
\hline 2005 & 49 & 63 & 99 & 109 & 65 & 293 & 261 & 272 & 175 & 56 & 72 \\
\hline 2006 & 51 & 64 & 68 & 77 & 56 & 247 & 138 & 235 & 189 & 49 & 53 \\
\hline 2007 & 39 & 69 & 80 & 101 & 56 & 291 & 176 & 309 & 176 & 54 & 65 \\
\hline 2008 & 47 & 59 & 74 & 59 & 68 & 307 & 221 & 265 & 177 & 46 & 50 \\
\hline 2009 & 31 & 63 & 72 & 67 & 56 & 243 & 206 & 246 & 196 & 40 & 51 \\
\hline 2010 & 34 & 42 & 64 & 83 & 49 & . & 150 & 215 & 162 & 23 & 49 \\
\hline 2011 & 32 & 39 & 77 & 83 & 60 & 119 & 190 & 239 & 202 & 40 & 47 \\
\hline 2012 & 21 & 35 & 63 & 77 & 55 & 117 & 181 & 238 & 123 & 31 & 39 \\
\hline 2013 & 26 & 38 & 51 & 70 & 49 & 117 & 142 & 187 & 164 & 30 & 30 \\
\hline 2014 & 18 & 38 & 66 & 63 & 57 & 105 & 157 & 195 & 176 & 33 & 47 \\
\hline 2015 & 23 & 41 & 48 & 61 & 46 & 103 & 134 & 162 & 136 & 27 & 44 \\
\hline 2016 & 18 & 46 & 66 & 48 & 44 & 103 & 119 & 227 & 136 & 33 & 41 \\
\hline 2017 & 32 & 38 & 65 & 48 & 35 & 107 & 81 & 236 & 159 & 28 & 37 \\
\hline 2018 & 37 & 44 & 55 & 44 & 34 & 101 & 103 & 193 & 155 & 31 & 35 \\
\hline 2019 & 28 & 43 & 59 & 61 & 34 & 117 & 118 & 171 & 140 & 34 & 32 \\
\hline
\end{tabular}

Source: authors 
Table 3. Balance of foreign trade in cereals in individual CEE countries in terms of value and by unit: 2005-2019

\begin{tabular}{|c|c|c|c|c|c|c|c|c|c|c|c|}
\hline \multicolumn{12}{|c|}{ Value (million euro) } \\
\hline & BG & HR & $\mathrm{CZ}$ & EE & HU & LV & LT & PL & RO & SK & SI \\
\hline 2005 & 162 & -12 & 188 & 2 & 424 & 34 & 102 & 37 & 50 & 51 & -42 \\
\hline 2006 & 163 & 17 & 123 & 12 & 593 & 30 & 61 & -39 & 102 & 120 & -54 \\
\hline 2007 & 38 & 42 & 171 & 28 & 1108 & 49 & 119 & -278 & -114 & 75 & -82 \\
\hline 2008 & 377 & -19 & 200 & 26 & 1155 & 123 & 241 & -461 & 331 & 4 & -64 \\
\hline 2009 & 300 & 71 & 276 & 14 & 838 & 116 & 233 & 209 & 378 & 160 & -36 \\
\hline 2010 & 494 & 61 & 220 & 20 & 1017 & 135 & 202 & 60 & 643 & 88 & -37 \\
\hline 2011 & 635 & 28 & 409 & 20 & 1231 & 72 & 182 & -119 & 731 & 145 & -67 \\
\hline 2012 & 762 & 88 & 436 & 75 & 1373 & 313 & 435 & 253 & 960 & 172 & -29 \\
\hline 2013 & 1129 & 71 & 377 & 64 & 1165 & 233 & 499 & 511 & 1669 & 163 & -52 \\
\hline 2014 & 859 & 40 & 440 & 65 & 1044 & 233 & 515 & 668 & 1691 & 199 & -55 \\
\hline 2015 & 813 & 78 & 477 & 128 & 1193 & 337 & 547 & 836 & 1468 & 242 & -35 \\
\hline 2016 & 969 & 105 & 473 & 91 & 1016 & 279 & 549 & 729 & 1506 & 273 & -32 \\
\hline 2017 & 813 & 97 & 465 & 131 & 1359 & 281 & 565 & 490 & 1551 & 255 & -30 \\
\hline 2018 & 973 & 118 & 337 & 85 & 1003 & 160 & 337 & 419 & 1836 & 182 & -32 \\
\hline 2019 & 1293 & 136 & 290 & 177 & 1192 & 374 & 635 & 414 & 2190 & 184 & -24 \\
\hline \multicolumn{12}{|c|}{ By unit (thousand tonnes) } \\
\hline & BG & HR & $\mathrm{CZ}$ & EE & HU & LV & LT & PL & RO & SK & SI \\
\hline 2005 & 1852 & -64 & 2086 & 43 & 3991 & 345 & 973 & 972 & 712 & 471 & -330 \\
\hline 2006 & 1725 & 178 & 1432 & 124 & 4931 & 258 & 565 & 135 & 1066 & 1225 & -394 \\
\hline 2007 & 368 & 274 & 1085 & 109 & 6870 & 268 & 531 & -1600 & -693 & . & -401 \\
\hline 2008 & 2266 & 51 & 1202 & 168 & 5837 & 650 & 1277 & -1853 & 2120 & . & -297 \\
\hline 2009 & 2657 & 645 & 2449 & 154 & 6092 & 767 & 1687 & 1916 & 3053 & 806 & -230 \\
\hline 2010 & 3320 & 413 & 1713 & 141 & 6171 & 814 & 1207 & 795 & 4078 & 387 & -196 \\
\hline 2011 & 3322 & 168 & 2233 & 99 & 5177 & 345 & 824 & -190 & 3477 & 400 & -283 \\
\hline 2012 & 3524 & 463 & 2308 & 315 & 5723 & 1350 & 1650 & 1359 & 3930 & 762 & -126 \\
\hline 2013 & 6187 & 447 & 2027 & 330 & 4858 & 1054 & 2213 & 2932 & 7959 & 884 & -221 \\
\hline 2014 & 5154 & 313 & 2797 & 398 & 4833 & 1233 & 2722 & 4154 & 8816 & 1202 & -236 \\
\hline 2015 & 4817 & 631 & 3158 & 758 & 6574 & 2010 & 2960 & 5000 & 7617 & 1475 & -138 \\
\hline 2016 & 6245 & 787 & 3568 & 602 & . & 1751 & 3328 & 4934 & 8515 & 1826 & -135 \\
\hline 2017 & 5108 & 743 & 3318 & 807 & . & 1614 & 3184 & 3289 & 8880 & 1707 & -154 \\
\hline 2018 & 5840 & 834 & 2253 & 424 & . & 780 & 1756 & 2738 & 10485 & 1046 & -151 \\
\hline 2019 & 7696 & 1103 & 1846 & 998 & . & 2089 & 3246 & 2847 &. & 1109 & -72 \\
\hline
\end{tabular}

Source: authors

In the EU, the leading exporters of potatoes are those in the North-Western Europe region (Firlej, Kubala, 2018). This is mainly due to its characteristics, as figures for crops harvested are relatively stable due to an increase in the volume of potato production despite the declining area of cultivation. In turn, these surpluses are mainly exported to CEE countries' markets, and therefore must have a negative balance in foreign trade. In value terms, the only countries with a surplus of exports over imports were Estonia (in 2010-2011), Latvia (2010) and Lithuania (2010-2015 and 2018). Specifically, such 
a situation occurred in Czechia (2007), Estonia (2011 and 2013), Latvia (2010), Lithuania (2010-2019) and Slovakia (2006-2007). When analysing foreign trade balances between 2005 and 2019, a downward trend is observed in terms of value and by unit. In the first, the trade balance improved only in Lithuania, whereas in the remaining countries it deteriorated, with Czechia and Hungary experiencing the most significant deterioration (by $5670 \%$ and $738.46 \%$ respectively). On the other hand, the situation improved in Croatia, Estonia and Lithuania.

Table 4. Foreign trade balance for potatoes in individual CEE countries in terms of value and by unit: 2005-2019

\begin{tabular}{|c|c|c|c|c|c|c|c|c|c|c|c|}
\hline \multicolumn{12}{|c|}{ Value (million euro) } \\
\hline & BG & HR & $\mathrm{CZ}$ & $\mathrm{EE}$ & HU & LV & LT & PL & RO & SK & SI \\
\hline 2005 & -3 & -7 & -1 & -1 & -3 & -1 & -3 & -20 & -9 & -5 & -4 \\
\hline 2006 & -3 & -11 & -12 & -1 & -6 & -1 & -6 & -28 & -16 & -11 & -9 \\
\hline 2007 & -5 & -10 & -22 & -1 & -10 & -2 & -8 & -58 & -11 & -15 & -11 \\
\hline 2008 & -4 & -10 & -9 & -1 & -5 & -1 & -5 & -25 & -13 & -7 & -9 \\
\hline 2009 & -3 & -7 & -10 & -1 & -5 & -2 & -2 & -25 & -9 & -9 & -8 \\
\hline 2010 & -4 & -9 & -18 & 0 & -9 & 0 & 1 & -41 & -10 & -19 & -7 \\
\hline 2011 & -5 & -10 & -29 & 0 & -12 & -2 & 1 & -59 & -21 & -28 & -8 \\
\hline 2012 & -4 & -8 & -5 & -1 & -4 & -1 & 0 & -24 & -15 & -12 & -6 \\
\hline 2013 & -7 & -14 & -31 & 0 & -7 & -1 & 5 & -32 & -17 & -22 & -12 \\
\hline 2014 & -6 & -9 & -25 & -1 & -7 & -2 & 2 & -37 & -18 & -20 & -9 \\
\hline 2015 & -6 & -11 & -21 & -1 & -7 & -2 & 0 & -25 & -15 & -17 & -6 \\
\hline 2016 & -7 & -12 & -34 & -1 & -14 & -3 & 0 & -37 & -32 & -26 & -8 \\
\hline 2017 & -9 & -7 & -28 & -2 & -16 & -3 & 0 & -23 & -26 & -21 & -12 \\
\hline 2018 & -8 & -11 & -28 & -2 & -21 & -3 & 1 & -32 & -27 & -21 & -12 \\
\hline 2019 & -13 & -14 & -58 & -1 & -22 & -4 & -2 & -82 & -64 & -30 & -11 \\
\hline \multicolumn{12}{|c|}{ By unit (thousand tonnes) } \\
\hline & BG & HR & $\mathrm{CZ}$ & EE & HU & LV & LT & PL & RO & SK & SI \\
\hline 2005 & -29 & -25 & -6 & -10 & -13 & -3 & -16 & -75 & -95 & -54 & -11 \\
\hline 2006 & -14 & -36 & -22 & -3 & -21 & -3 & -24 & -99 & -140 & 12 & -24 \\
\hline 2007 & -26 & -26 & 29 & -3 & -28 & -6 & -28 & -157 & -39 & 373 & -23 \\
\hline 2008 & -17 & -22 & -41 & -2 & -21 & -3 & -15 & -48 & -45 & -24 & -21 \\
\hline 2009 & -22 & -15 & -66 & -7 & -23 & -10 & -9 & -98 & -46 & -45 & -22 \\
\hline 2010 & -18 & -25 & -104 & 0 & -33 & 1 & 4 & -199 & -44 & -82 & -16 \\
\hline 2011 & -15 & -17 & -115 & 2 & -33 & -7 & 4 & -166 & -78 & -70 & -17 \\
\hline 2012 & -24 & -16 & -56 & -1 & -20 & -6 & 3 & -73 & -155 & -35 & -17 \\
\hline 2013 & -35 & -27 & -122 & 1 & -17 & -1 & 26 & -61 & -125 & -56 & -28 \\
\hline 2014 & -31 & -13 & -171 & -2 & -27 & -7 & 6 & -150 & -109 & -58 & -22 \\
\hline 2015 & -37 & -21 & -181 & -1 & -33 & -8 & 6 & -125 & -106 & -61 & -17 \\
\hline 2016 & -33 & -26 & -167 & -2 & . & -12 & 7 & -111 & -162 & -57 & -21 \\
\hline 2017 & -47 & -14 & -163 & -7 & . & -13 & 6 & -73 & -116 & -54 & -31 \\
\hline 2018 & -39 & -23 & -166 & -7 & . & -11 & 9 & -111 & -136 & -56 & -20 \\
\hline 2019 & -39 & -19 & -200 & -4 & . & -10 & 8 & -246 & . & -57 & -21 \\
\hline
\end{tabular}

Source: authors 
Differentiation in the consumption of particular agricultural products in relation to production for 2005-2017 is presented in Figure 1. In the production of cereals, only one third is intended for human consumption with the remaining used as animal feed. There is a chance to produce enough (not including beer) from domestic production in all the countries on this market.

Those with a surplus of potatoes every year were Poland, Lithuania and Romania. Until 2014 this was found in Hungary too, until 2013 (except 2010 and 2012) in Latvia, and until 2007 in Slovenia. After 2015 desirable indicator values (below 100) were found in Croatia; after 2016 in Czechia and 2017 in Bulgaria. In Estonia and Slovakia, annual values are above 100 , which indicates that these countries did not meet local needs by domestic production. Since 2008, this situation has been found in Slovenia as well.

Figure 1. Consumption volume index per production volume in individual CEE countries: 2005$2017(\mathrm{~kg} / \mathrm{kg})$

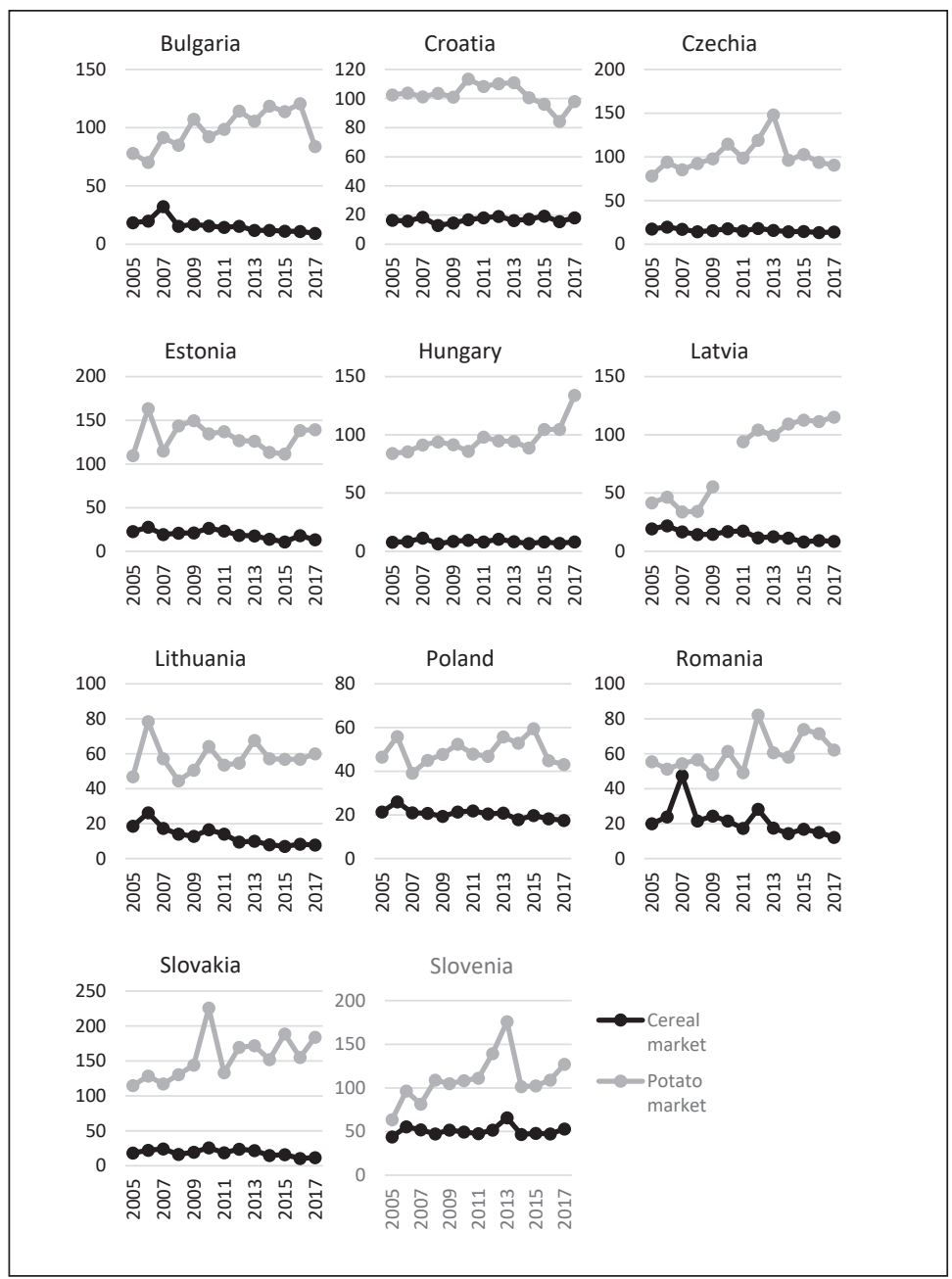

Source: authors 


\section{Conlusions}

Observing the changes taking place in the cereal and potato markets is extremely important due to the need to create or modify concepts that can significantly affect farm businesses' growth. Research on self-sufficiency has allowed the following conclusions to be drawn:

- CEE countries show a significant degree of diversity in terms of self-sufficiency in cereals and potatoes;

- on the cereal market, a secure food situation is found in practically all CEE countries covered by the analysis, except Slovenia which has a negative trade balance as well as the lowest production volume index value per capita;

- the most secure potato situation is found in such countries as Lithuania, Poland and Romania. These countries can satisfy demand with their production. A high level of self-sufficiency is also present in Latvia. A characteristic feature of the potato market is a decrease in the volume of production per capita, mainly due to increased competition with potato producers from Western Europe;

- taking both cereal and potato markets into account, Lithuania and Poland are the most successful in self-sufficiency. A relatively secure situation is found in Latvia and Romania. There is a great natural and economic potential in these countries that may increase competitiveness in individual agricultural markets. The opposite situation is found in Slovenia.

It should be remembered that despite the good position of Poland and other EU countries, food security and food self-sufficiency must be continuously checked and analysed appropriately. Governments should take appropriate action to prevent undesirable events, and the Common Agricultural Policy should remain the basis of the EU's food security policy. It is recommended that agricultural expenditure be maintained at a stable level, giving farmers a fair income and ensuring producers are protected from price volatility. It is also becoming essential to prevent food waste in the entire agri-food chain in the EU.

\section{References}

Anderson, K., Strut, A. (2012). Agriculture and Food Security in Asia by 2030. ADBI Working Article, 368 .

Baer, A. (2002). Wpływ rozszerzenia Unii Europejskiej na samowystarczalność żywnościową na tle poziomu konsumpcji. Roczniki Naukowe SERiA, 4(2), 12-17.

Baer-Nawrocka, A. (2014). Zmiany w spożyciu i stopniu samowystarczalności żywnościowej w Unii Europejskiej. Prace Naukowe Uniwersytetu Ekonomicznego we Wrocławiu, 360, 19-27. doi: $10.15611 / \mathrm{pn} .2014 .360 .02$

Bne Saad, M. (2013). The Global Hunger Crisis: Tackling Food Insecurity in Developing Countries. London: Pluto Press.

Borch, A., Kjaernes, U. (2016). Food security and food insecurity in Europe: An analysis of the academic discourse (1975-2013). Appetite, 103, 137-147.

Burchi, F., Fanzo, J., Frison, E. (2011). The Role of Food and Nutrition System Approaches in Tackling Hidden Hunger. International Journal of Environmental Research and Public Health, 8(2), 358-373.

Bureau, J.C., Swinnen, J. (2018). EU policies and global food security. Global Food Security, 16, 106-115. 
Carletto, C., Zezza, A., Banerjee, E. (2013). Towards better measurement of household food security: Harmonising indicators and the role of household surveys. Global Food Security, 2(1), 30-40.

FAO. (2003). Trade Reforms and Food Security. Conceptualising the linkages. Rome: FAO, 26-27.

Firlej, K., Kubala, S. (2018). Asymetria samowystarczalności produkcji ziemniaków w krajach Unii Europejskiej. Roczniki Naukowe SERiA, 20(2), 37-45. doi: 105604/01.3001.0011.8113

Global Food Security Index 2019. (2020). Retrieved from: https://foodsecurityindex.eiu.com/Downloads

Grębowiec, M. (2012). Wpływ integracji Polski z Unią Europejską na zmiany w podejściu do zapewnienia jakości produktów żywnościowych. Zeszyty Naukowe SGGW w Warszawie, Problemy Rolnictwa Światowego, 12(27), 63-74.

Gulbicka, B. (2009). Problemy wyżywienia w krajach rozwijających się. Publikacje Programu Wieloletniego 2005-2009, 124, 33-78.

Gulbicka, B., Kwasek, M., Obiedzińska, A. (2015). Z badań nad rolnictwem społecznie zrównoważonym [33]. Analiza bezpieczeństwa żywnościowego Polski. Monografie Programu Wieloletniego, 19.

Hałasiewicz, A. (2011). Rozwój obszarów wiejskich $w$ kontekście zróżnicowań przestrzennych $w$ Polsce i budowania spójności terytorialnej kraju. Ekspertyza wykonana dla Ministerstwa Rozwoju Regionalnego. Warszawa.

Johnson, R. (2002). Dietary Intake - How Do We Measure What People Are Really Eating? Obesity, 10(11), 63-68.

Kapusta, F. (2011). Zboża w rolnictwie i gospodarce Polski. Wieś Jutra, 3-5.

Kapusta, F. (2012). Agrobiznes. Warszawa: Difin.

Kowalczyk, S., Sobiecki, R. (2011). Europejski model rolnictwa wobec wyzwań globalnych. Zagadnienia Ekonomiki Rolnej, 4(329), 35-58.

Kraciuk, J. (2013). Suwerenność żywnościowa a procesy globalizacji w rolnictwie. Folia Pomeranae Universitatis Technologiae Stetinensis, 70, 122-123.

Kubala, S. (2018). Changes in Self-Sufficiency in Beef and Pork in Selected Central and Eastern Europe Markets. Problemy Zarzadzania, 6(79), 96-107. doi: 10.7172/1644-9584.79.4

Kwasek, M., Obiedzińska, A. (2013). Spożycie żywności a środowisko. In: Z badań nad rolnictwem społecznie zrównoważonym [20]. Wybrane zagadnienia zrównoważonego rozwoju rolnictwa. Publikacje Programu Wieloletniego 2011-2014, 93, 139-152.

Lyon, G. (2010). Report on the future of the Common Agricultural Policy after 2013. Belgium: European Parliament, Committee on Agriculture and Rural Development, (2009/2236(INI)).

Mikuła, A. (2012). Bezpieczeństwo żywnościowe Polski. Roczniki Ekonomii Rolnictwa i Rozwoju Obszarów Wiejskich, 99(4), 39-40.

Nietupski, T., Szybiga, K. (2002). Bilans żywnościowy województwa dolnośląskiego. Roczniki Naukowe SERiA, 4(1), 138-141.

Poczta, W. (2011). Wspólna Polityka Rolna Unii Europejskiej po 2013 roku - wizje zmian. In: A. Czyżewski, W. Poczta (eds.), Projekty inwestycyjne w agrobiznesie a zasady Wspólnej Polityki Rolnej po 2013 roku. Poznań: Wydawnictwo Uniwersytetu Ekonomicznego w Poznaniu, 62-77.

Rome Declaration on World Food Security and World Food Summit Plan of Action. (1996). World Food Summit, 13-17 November 1996, Rome Italy. Retrieved from: http://www.fao.org/3/w3613e/ w3613e00.htm

Sadowski, A., Girzycka, W. (2012). Charakterystyka gospodarstw korzystających ze wsparcia inwestycji modernizacyjnych i dostosowawczych na tle innych form pomocy Unii Europejskiej. Journal of Agribusiness and Rural Development, 1(23), 124-125.

Sektorowa strategia bezpieczeństwa $w$ działach administracji rządowej rolnictwo, rozwój wsi, rynki rolne, rybołówstwo. (2008). Warszawa: Ministerstwo Rolnictwa i Rozwoju Wsi.

Servolin, C. (2005). Gospodarka rolna - między polityką a ekonomią. Wieś i Rolnictwo, 4(129).

Skrzypczyńska, J. (2011). Międzynarodowe aspekty reform Wspólnej Polityki Rolnej Unii Europejskiej. Przegląd Prawa Rolnego, 1(8), 89-108. 
Strategia zrównoważonego rozwoju wsi, rolnictwa i rybactwa 2030. (2020, 27 July). Retrieved from: https://www.gov.pl/web/rolnictwo/strategia-zrownowazonego-rozwoju-wsi-rolnictwa-i-rybactwa-2030

Szczepaniak, I. (2012). Samowystarczalność żywnościowa Polski. Przemysł Spożywczy, 2, 2-3.

Szybiga, K. (2013). Asymetria spożycia i produkcji wybranych artykułów żywnościowych w ujęciu przestrzennym. Zagadnienia Ekonomiki Rolnej, 1, 104-117.

Tomczak, F. (2009). Ewolucja wspólnej polityki rolnej UE i strategia rozwoju rolnictwa polskiego. Publikacje Programu Wieloletniego 2005-2009, 125.

Wilkin, J. (2001). Polskie rolnictwo wobec procesu globalizacji. Roczniki Naukowe SERiA, 3(1), 9-20.

Sebastian Kubala, MA, is a $\mathrm{PhD}$ candidate, speciality economics sciences and the author or co-author of about twenty scholarly contributions. His research interests centre around the food industry, particularly research related to land economy, prices on food markets, and the EU's agricultural policy. A significant part of his interest is focused on issues of business management.

ORCID: https://orcid.org/0000-0003-4021-9173

\section{Address:}

Uniwersytet Ekonomiczny w Krakowie

Kolegium Ekonomii, Finansów i Prawa

Katedra Rozwoju Organizacji

ul. Rakowicka 27

31-510 Kraków, Polska

e-mail: kubalas@uek.krakow.pl

Chrystian Firlej, MA, graduate of the Cracow University of Economics, currently an employee and doctoral student of the University of Agriculture in Krakow. He completed post-graduate studies at Cracow Business School, part of the Cracow University of Economics, in the eurozone field. He deals with academic and research issues in the functioning of companies belonging to the WIG Spożywczy index on the Warsaw Stock Exchange and is an author or co-author of publications in this area. His main research interests are in the agri-food market in Poland and the EU.

ORCID: https://orcid.org/0000-0001-7724-5717

\section{Address:}

Uniwersytet Rolniczy w Krakowie

Wydział Rolniczo-Ekonomiczny

Katedra Zarządzania i Ekonomii Przedsiębiorstw

al. Adama Mickiewicza 21

33-332 Kraków, Polska

e-mail: c.firlej@urk.edu.pl

The article is financed within the subsidy granted to the Cracow University of Economics (Program Potencjał No 13/ EER/202/POT). 